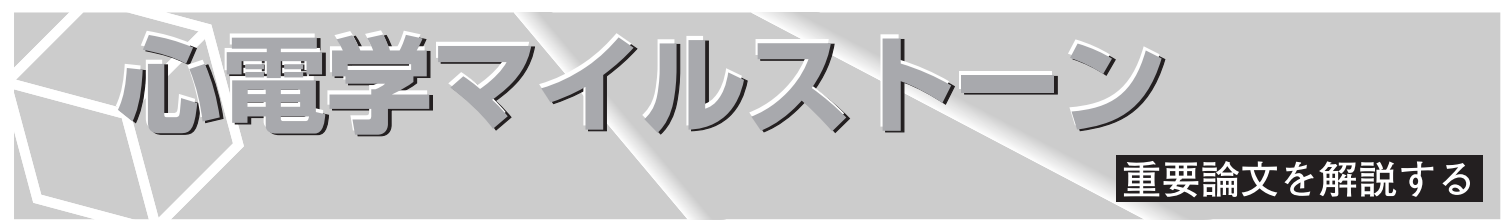

\title{
因田恭也 (名古屋大学大学院循環器内科学)
}

Relative merits of left ventricular dyssynchrony, left ventricular lead position, and myocardial scar to predict long-term survival of ischemic heart failure patients undergoing cardiac resynchronization therapy.

Delgado V,van Bommel RJ, Bertini M, Borleffs CJ, Marsan NA,Arnold CT Nucifora G, van de Veire NR,Ypenburg C, Boersma E, Holman ER, Schalij MJ, Bax JJ

Circulation, $2011 ; 123: 70 \sim 78$

心臟再同期療法 (cardiac resynchronization therapy：CRT) は，収縮同期不全のある重症 心不全に対する有用な治療法である。しかし， この治療法に効果を示さない non-responder がおよそ $30 \%$ も存在する. CRTの治療費は 高額であり, 手技による合併症の危険もとも なうことから, responder を予知する多くの 試みがこれまでに行われてきた，CRTは非 同期性を改善する治療であるため, 非同期性 を証明することがCRT responder 予測につ ながると考えられた．しかし，QRS 幅や心工 コーの多くの dyssynchrony 指標は, いずれ も responder を十分に予測できなかった.

本論文で Delgado らは単一の指標ではな く, 心エコーによる左室収縮時間差 (radial strain 法によるdyssynchrony), 左室リード 位置 (もっとも遅く収縮する部位に位置する か否か), および左室リード留置部位の収縮性 (radial strain 法による心筋厚みの変化率)の 3 種類の指標を組み合わせることで, CRT 長
期予後を検討した。エンドポイントはこれま での報告でしばしば用いられてきた左室収縮 末期容量や駆出率, NYHA クラスの変化では なく, 全死亡とした.

その結果, 心エコーによる収縮非同期性が 大きい, 左室リードが左室収縮遅延部位に留 置される，左室リード留置部位が痏痕でない 場合に, CRT 予後が優れていることが示さ れた。 さらにこれらの条件がそろうほどに予 後が改善するとわかった。これらの指標は 個々にはCRT responder を予知するとして これまでにも報告されてきたものの，組み 合わせ方次第で, さらに効率的にCRT responder を予測できるものと期待される.

本論文は CRT において非同期性のみなら ず，左室収縮性やリード位置の重要性を示し ている．今後これらの評価方法や組み合わせ 方の検討が予想される。手前味噌であるが, i-Index (Heart Rhythm, $2010 ; 7: 655$ 661) も参照されたい。 